\title{
NEW SPIRITUALITY, POLITICS OF SELF-EMPOWERMENT, CITIZENSHIP AND DEMOCRACY IN CONTEMPORARY INDIA
}

\author{
Short title: New spirituality, politics and democracy \\ Nandini Gooptu \\ St Antony's College, Oxford OX2 6JF \\ Email: nandini.gooptu@qeh.ox.ac.uk
}

\begin{abstract}
India has seen a recent upsurge in spiritual practices promoted by an entrepreneurial breed of leaders and organisations. Their primary preoccupation is not to preach religious faith and belief or to promote ritual practice, but to provide guidance on psychological and physical well-being, happiness and healthy lifestyle. They offer strategies of healing and re-energising, and advocate self-management and self-development as tools of both material advancement and mental contentment. Spiritual practices emphasise individual agency, personal empowerment and reliance on one's own 'inner' resources, and valorise the autonomous self-governed citizen as the protagonist of a modern and modernising nation. While being reminiscent of the sacralisation of everyday life and the rise of the 'self-ethic' in New Age spiritual movements in the West, the Hindu versions of new spirituality in India draw upon religious traditions and construct a narrative of laicisation of the esoteric and people-centric spirituality, consonant with the prevalent democratic zeitgeist. This paper explores the implications of these developments for political subjectivity, religious identity, and notions of citizenship and democracy.
\end{abstract}

\section{Introduction: Spirituality and Politics of the Self}

On a Sunday morning in August in Calcutta, several dozen middle class members of the wellknown and highly popular spiritual organisation, Art of Living Foundation (AoL), who are followers of the guru (religious preceptor or teacher) Sri Sri Ravi Shankar, arrived in one of the city's slums, inhabited mainly by rag pickers and general labourers working in the informal sector. The AoL members were engaged in a campaign to create awareness about the detrimental ecological impact of the use of plastic bags. This environmental initiative was undertaken in alliance with a neighbourhood youth club with whom AoL members had been working for a while to teach spoken English as well as spiritual practices and meditation to slum children and young people. The campaign on that Sunday took the form of a procession through the narrow streets of the sprawling slum, lined with the hutments of local residents as well as large bales of waste material, paper and plastic, ready for resale, that being the main livelihood of many of the residents. The procession was led by bands of local school children playing musical instruments, having been mobilised by the members of the local club, and also by two colourfully dressed men on stilts who towered over the low, single storied dwellings and drew attention to the procession. Running commentary was provided on a loud speaker about the multifarious evils of plastic bag use and the detrimental effects on health and hygiene in the neighbourhood. The procession ended with a meeting near the busy Sunday street market area, where many bemused 
buyers found their plastic bags politely taken away by AoL members and replaced with jute bags. AoL representatives, as well as youth club members, gave speeches at the meeting, which was also attended by municipal officials and the local councillor, who spoke of the need to address the problem of urban pollution. While the councillor clearly saw this gathering as a useful political opportunity to address his constituents, a couple of AoL members stated that they had espoused a pragmatic strategy of collaboration with political parties in order to advance their own sewa (social service) and spiritual work in the neighbourhood.

In June 2011, Baba Ramdev, one of India's most prominent spiritual figures and yoga gurus, usually seen on religious television channels every morning demonstrating yoga postures at mass gatherings of his followers, was featured live on every national and regional news channels over a few days for twenty-four hours, as he staged a public fast in the capital city of Delhi at the usual site of political protests - the Ramlila Maidan. Ramdev's mission was to cleanse politics of graft and bribery, and to stamp out the culture of black money in the country, by pressurising the national government to introduce anti-corruption legislation. Having failed to persuade Ramdev to suspend his fast and fearing an adverse political fallout, late at night the government sent in the police to remove Ramdev from the site of his protest, where many of his supporters were also camping for the night. In the confusion that ensued, Ramdev managed to escape, even while television cameras filmed the incident. He was later arrested in the vicinity of the protest ground, away from the cameras, as he tried to flee from the police, disguised as a woman, apparently wearing clothes borrowed from a female devotee. The following day he was accompanied by the police to his ashram (monastery) at Hardwar in north India and released there from custody, where the television cameras caught up with him again. He then addressed the nation on television, still dressed as a woman in white, instead of changing into his usual saffron robes, thus symbolically representing the most oppressed sections of the country's citizens as well as the purity of those wronged by a tainted and dominant state. He denounced the political order for not only engaging in and facilitating corruption, but also for perpetrating violence on, and abusing the rights of ordinary, defenceless and down-trodden citizens, who desired to create a spiritually and ethically reinvigorated nation.

These two events reveal the central significance of spirituality in India's democratic political culture today. Spirituality informs the ethics and morality of public action, spanning the local micro-level to the national seat of government, and embraces issues of social activism, party politics, state power, citizenship, and nationalism. Spiritual practices in India, including reverence for gurus, while already widespread, have, in the past couple of decades, in the wake of globalisation and economic liberalisation, assumed a 'mass' dimension as well as a consumerist, commercialised orientation, prompting Meera Nanda to coin the term 'God Market', in the eponymous book that documents the nexus of Hindu nationalist politics and spirituality, as well as its corporatisation and marketisation. ${ }^{1}$ Yoga, meditation, ayurvedic (ancient Hindu system of medicine) herbal remedies and traditional healing practices are all now widely prevalent, and even part of big business, along with spirituality as a method of stress and anger management and as a motivational tool for positive thinking and personality development, practised by anyone from students to housewives, and corporate executives to NGOs in slums working with the poor. The growing importance of spirituality in business and managerial practices is now well recognised, ${ }^{2}$ while analysts have commented that Hindu spiritual practices,

\footnotetext{
${ }^{1}$ Meera Nanda (2009), The God Market: How Globalization is Making India More Hindu, Random House, Noida.

${ }^{2}$ Christopher Fuller and John Harriss (2005), 'Globalizing Hinduism: The "Traditional" Teaching of Swami

Dayananda Saraswati and Modern Business in Chennai', in Assayag, J. and Fuller, C. J. (eds), Globalizing India:
} 
as a form of 'soft Hindutva' or Hindu identity, often feed into the more organised Hindu nationalism of the Bharataiya Janata Party. ${ }^{3}$ However, the much broader and deeper implications of spirituality for conceptions of the nation and social contract with the state, as well as notions and practices of citizenship and democracy, remain to be examined.

The recent flowering of spirituality in India is not primarily concerned with ritual practice, faith or religious community mobilisation, but is concentrated on personal psychological and physical well-being, happiness and healthy lifestyle. Sri Sri Ravi Shankar, a key exponent of contemporary spirituality describes it as follows:

Understanding this mind of ours, understanding the memory, the ego, the self, the source of life, understanding our life is spirituality. ... Love, joy, bliss, compassion, beauty and enthusiasm are all made of the spirit. Enlivening these is spirituality. ${ }^{4}$

As evident from this comment, the distinctive hallmark of spirituality today is an introspective focus on the individual self. The term New Spirituality (hereafter NS) is used in this paper to refer to this recent spiritual upsurge, not because it marks a break with the past or has no historical antecedents, but to signal the centrality of the individual self in the contemporary variant of spirituality as its distinctive feature. The paper explores how NS recasts conceptions of self-hood, democratic norms and practice, notions of citizenship and national identity.

NS is a term usually used to refer to New Age movements in the West that are concerned with the autonomous individual self, and that emphasise the importance of a 'self-ethic', inner consciousness and personal subjective experience. ${ }^{5} \mathrm{NS}$ became prominent in the West from the 1960s, and drew upon both oriental philosophies (Hinduism and Buddhism) and pagan or preChristian ideas and practices. NS in the West is usually understood in terms of a process of secularisation or 'de-traditionalisation', referring to the decline of the authority of organised religion and institutionalised religious practice and ritual, particularly that of the Christian Church, as well as an erosion of belief in a transcendent theistic God. ${ }^{6}$ Some contemporary expressions of spirituality in India, such as that of AoL, are based on variants of Indian and other Asian versions of spirituality that travelled to the West in the 1960s, '70s and '80s, and developed as a part of the corpus of New Age practices, absorbing new ideas along the way, ${ }^{7}$

Perspectives from Below, Anthem Press, London, pp. 211-236; Thomas Birtchnell (2009), 'From "Hindolence" to "Spirinomics": Discourse, practice and the myth of Indian enterprise', South Asia: Journal of South Asian Studies, 32(2), pp. 248-68; Carol Upadhya (2013), 'Shrink Wrapped Souls: Managing the self in India's new economy', in Gooptu, Nandini (ed.), Enterprise Culture in Neoliberal India, Routledge, London, pp. 93-108.

${ }^{3}$ Nanda, God Market, p. 99.

${ }^{4}$ Spirituality: Talks by H. H. Sri Sri Ravishankar, Sri Sri Publications, Bangalore, 2007, pp. 34-35.

${ }^{5}$ Paul Heelas (1996), The New Age Movement: The Celebration of the Self and the Sacralisation of Modernity, Blackwell, Oxford, pp. 23-4; Paul Heelas and Linda Woodhead (2005), The Spiritual Revolution: Why Religion is Giving Way to Spirituality, Blackwell, Oxford, pp. 1-11; Gordon Lynch (2007), New Spirituality: An Introduction to Belief Beyond Religion, I. B. Tauris, London, New York, pp. 53-60; Gordon Lynch (2008), 'Dreams of the autonomous and reflexive self: The religious significance of contemporary lifestyle media' in Spalek, Basia and Imtoual, Alia (eds), Religion, Spirituality and the Social Sciences: Challenging Marginalization, Policy Press, Bristol, pp. 63-75.

${ }^{6}$ Heelas, New Age Movement, pp. 15-29; Paul Heelas (2008), Spiritualities of Life: New Age Romanticism and Consumptive Capitalism, Blackwell, Oxford, p. 6.

${ }^{7}$ Patrick Pasture (2011), 'Religious Globalization in Post-war Europe: Spiritual connections and interactions', Archiv für Sozialgeschichte, 51, pp. 63-108; Kathinka Frøystad (2009), 'The Return Path: Anthropology of a Western Yogi' in Csordas, Thomas J. (ed.), Transnational Transcendence: Essays on Religion and Globalization, University of California Press, Berkeley, pp. 279-304. 
ranging from psychotherapy and business management to self-help and self-care, to notions of freedom, choice and personal autonomy in religious practice, that have now come to appeal to the Indian middle classes. ${ }^{8}$ Frøystad has described this circulation of ideas in terms of a 'return path' or 'return globalisation' 'whereby a phenomenon gathers momentum after having gained fame abroad'. ${ }^{9}$ Despite some obvious similarities with western forms of spirituality however, Indian new spirituality cannot be considered a mere extension of returning westernised varieties, but has to be understood as an autonomous phenomenon rooted in its own specific spatial and temporal context of a late post-colonial, mature democracy undergoing globalisation. Moreover, some contemporary varieties of NS in India, such as that of Ramdev, do not espouse westernised versions, but draw upon colonial and post-colonial nationalist constructions of yoga and related spiritual practices that assert the unity of the mind, body and the soul against the influences of imperialism and western, scientific modernity. ${ }^{10}$ Some recent forms of spirituality are also reminiscent of Bhakti (devotional tradition in Hinduism) notions of introspective devotionalism and oneness with the divine, as well as humanistic spirituality and self-realisation through humanitarian service, associated with Swami Vivekananda and other proponents of 'neoHindusim' in the nineteenth and early twentieth centuries, who offered new readings of the Vedanta. ${ }^{11}$

While the academic literature shows analytical unanimity on the centrality of the self in NS, scholars writing on the West harbour widely divergent evaluations of its social and political meaning and significance. ${ }^{12}$ Moreover, a number of different varieties of spirituality have been identified, which underscores that NS consists of a differentiated set of practices with plural interpretations and multiple perspectives. Gordon Lynch distinguishes right-wing, socially conservative spirituality from those with a left-of-centre, anti-establishment political bent, which he celebrates as a progressive liberal force, in tune with religious syncretism, humanism, feminism and environmentalism, and as a resource for ethical and moral activism and 'a basis for mutual identification and collaboration with other like-minded people'. ${ }^{13}$ Heelas has argued that 'inner life' humanist spirituality in countries like India and Pakistan can serve as a bulwark against sectarian and exclusivist religious identity and conflict, and can also provide the moral imperative to galvanise action for poverty eradication and social equality. ${ }^{14}$ In contrast to this view, NS practices have been condemned either for their singular focus on the self, breeding atomised individualism and political and social disengagement, or for political conformism. ${ }^{15}$ Against this assessment of NS as apolitical or anti-political, however, David Tacey describes some forms of spirituality as a democratic spiritual groundswell in quest of a 'universal language of the spirit', common values, mysticism and romanticism. This form of spirituality rejects the equally unattractive options of religious fundamentalism and post-enlightenment secularism,

\footnotetext{
${ }^{8}$ Maya Warrier (2005), Hindu Selves in a Modern World: Guru Faith in the Mata Amritanandamayi Mission, RoutledgeCurzon, London, New York, pp. 14-15.

${ }^{9}$ Frøystad, 'The Return Path', p. 279.

${ }^{10}$ Peter van der Veer (2007), 'Global Breathing: Religious Utopias in India and China', Anthropological Theory, 7(3), pp. 315-328; Joseph S. Alter (1997), 'A Therapy to Live by: Public Health, the Self and Nationalism in the Practice of a North Indian Yoga Society', Medical Anthropology, 17(4), pp. 309-335.

${ }^{11}$ Gwilym Beckerlegge (2006), Swami Vivekananda's Legacy of Service: A Study of the Ramkrishna Math and Mission, Oxford University Press, New Delhi, pp. 205-19.

${ }^{12}$ Heelas, Spiritualities of Life, pp. 5-8.

${ }^{13}$ Lynch, New Spirituality, p. 42 and passim.

${ }^{14}$ Heelas, Spiritualities of Life, Epilogue.

${ }^{15}$ Jeremy R. Carrette and Richard King (2005), Selling Spirituality: The Silent Takeover of Religion, Routledge, London, New York, passim.
} 
Tacey argues. He sees 'a people's revolution' taking shape that is 'existential rather than creedal', with 'individuals taking authority in their own hands' and posing 'a direct political and philosophical challenge to traditional notions of sacredness and the holy'. ${ }^{16}$

This paper draws upon these diverse insights to analyse the spectacular expansion of new spirituality in India in the past two decades, arising as it has done, not only in the specific context of expansion of consumer and corporate culture, but also the significant acceleration of political democratisation. The wider scholarly literature provides useful analytical frames to approach the Indian case, but of course, the political significance of NS in India today will not be inferred directly from that literature, and will be interpreted in light of the contextual specificities of India's democratic polity. In particular, this paper investigates modes of self-fashioning through new spirituality, and examines its implications for the creation of new political subjectivities and for religious and national identity and democratic politics. The relations of NS with organised forms of Hindu nationalist or fundamentalist politics have been explored in the secondary literature, ${ }^{17}$ and hence, not examined her. This paper is chiefly concerned with individual identity and, with what might be called, the politics of the self, which is a largely unexplored theme in the literature on religion and politics in India. Sociological understanding of Indian identity has tended to emphasise the 'subordination of the individual to the imperatives of the collective', such as the family or caste, leading to limited analytical engagement with self-oriented forms of religious identity. ${ }^{18}$ Similarly, colonial anthropological constructions of Indian society essentialised communities as the fundamental units of social organisation under which individuals are supposedly subsumed. Scholarly preoccupation with organised forms of religious nationalism, communal conflict and caste group-based politics has also hitherto contributed to historical and political analysis of religion and politics in India to concentrate on community identity formation, collective action, group mobilisation and social movements. However, contemporary spirituality, globally and in India, is primarily concerned with the individual-self, and it entails intensely personalised religious experience, and the politicisation and sacralisation of personal identity. Further, as Gordon Lynch notes, NS involves the expression of individuality and the experience of autonomous, reflexive individuals. ${ }^{19}$ As such, any interpretation of the political significance of contemporary forms of spiritual practice requires liberation from the analytical strait-jacket of collective action and identity. It is necessary to open up an interpretative terrain to engage with individual identity and politics in a personalised and individualised mode.

It should be emphasised here though that the study of individualised modes of politics does not imply a lapse into methodological individualism by reducing social and political developments and phenomena to the properties and motivations of individuals. Instead, an analytical strategy is advocated that takes individualised manifestations of politics seriously, but seeks to interpret and explain them in terms of shifts in social organisation, institutions or discourses. Moreover, an emphasis on the individual and politics of the self is not intended to deny or ignore the importance of group action, nor to take individualisation of politics to be synonymous with individualism, that may denote atomistic isolation from society and the

\footnotetext{
${ }^{16}$ David Tacey (2004), The Spirituality Revolution: The Emergence of Contemporary Spirituality, BrunnerRoutledge, Hove, New York, pp. 3-4, 7, passim.

${ }^{17}$ Nanda, God Market; Lise McKean (1996), Divine Enterprise: Gurus and the Hindu nationalist movement, University of Chicago Press, Chicago.

${ }^{18}$ Warrier, Hindu Selves, p. 15.

${ }^{19}$ Lynch, 'Dreams of the autonomous and reflexive self', pp. 64-66.
} 
singular pursuit of self-interest. Instead, it is recognised that individualised politics of the self is compatible with, and may even require, collaborative as well as altruistic action to achieve the full potential of the self, and may range from philanthropic participation in cooperative networks to the formation of associations of like-minded people. Likewise, individual-oriented politics does not necessarily entail solitary and solipsistic practices in the private domain, but collective or congregational practices can be important. However, instead of individuals deriving their identity or sense of belonging from the collective, they relate to it in terms of their own preoccupations and imperatives of self-making as individuals. This is perhaps best captured by Zygmunt Bauman's coinage, 'Individually, Together', ${ }^{20}$ which indicates that the animating force behind group action is the construction of individual biography, not collective identity or a sense of political unity. This is poignantly manifested in the familiar image of a mass of people sitting together in public yoga sessions today, but all engaged in their own personal and private meditation with eyes closed and each poised in individual yogic acts in quest of selfenhancement and self-care. The political significance of this is fundamentally different from a mass demonstration of yoga and calisthenics as an expression and articulation of the collective strength and identity of a community, as done by some Hindu nationalist organisations.

Similarly, Kevin McDonald, writing about contemporary forms of spirituality in China, uses the concept of 'affinity group', in which 'each person enters into a relationship with concrete others, as opposed to relating to the totality'. ${ }^{21}$ In order to engage simultaneously with the subjective turn and individualisation, on the one hand, and forms of cooperation, on the other, Heelas and Woodhead draw attention to the relational aspects of subjectification by distinguishing between 'individuated' and 'relational subjectivism', with the former being focussed on individualism and the latter on interdependence. Heelas and Woodhead clarify that this latter variety of 'subjectivelife spirituality is "holistic", involving self-in-relation rather than self-in-isolation'. ${ }^{22}$

With or without collective or relational activities, individualised forms of politics have profound implications and wider significance, as highlighted by Asef Bayat. ${ }^{23}$ Writing about politics in the Middle East, Bayat has formulated the concept of social 'nonmovements' of 'noncollective actors', to draw attention to disparate but widespread and simultaneous ordinary, quotidian practices of individuals, which he calls 'life as politics'. These practices may lack any recognisable ideology, organisation or leadership, but they have a common underlying logic or disposition, and together they reshape societal norms, values and beliefs. In this way, they have an important cumulative impact on institutions and wider politics. Bayat contends that social 'nonmovements' of 'noncollective actors' came to pose a challenge to authoritarian regimes in the Middle East. In the Indian context, the question of overcoming authoritarian governments is not of similar significance, but Bayat's arguments about the power of individualised actions and practices in redefining political culture is germane to India in analytically grasping the implications of individualised modes of politics in NS.

The discussion in this paper is based on AoL of Sri Sri Ravi Shankar and on Baba Ramdev, both by far the best known in contemporary Indian NS. They are primarily concerned

\footnotetext{
${ }^{20}$ Zygmunt Bauman (2008), 'Foreword: Individually, Together', in Beck, Ulrick and Beck-Gernsheim, Elisabeth, Individualization: Institutionalized Individualism and Its Social and Political Consequences, Sage, Los Angeles, London, p. xiv.

${ }^{21}$ Kevin McDonald (2004), 'Oneself as Another: From Social Movement to Experience Movement', Current Sociology, 52(4), p. 585.

${ }^{22}$ Heelas and Woodward, Spiritual Revolution, p. 11.

${ }^{23}$ Asef Bayat (2010), Life as Politics: How Ordinary People Change the Middle East, Stanford University Press, Stanford, pp. 14-26.
} 
with yoga, meditation, health and well-being, and they represent the kind of gurus who are now the most popular and influential in India. In her taxonomy of god-men and women, Meera Nanda identifies them as 'Type 3' gurus 'who have taken the country by storm in recent years', and who are distinct from previously more popular 'Type 1' gurus revered for their miraculous and divine powers, and 'Type 2' gurus venerated for their knowledge of theology and religious doctrine. ${ }^{24}$ As stated above, this essay seeks to unravel the political implications and significance of NS. The essay is not concerned with the reasons for the rapidly expanding popularity of NS of Type 3 gurus, nor with the nature and causes of uptake of spiritual ideas and practices from the perspective of practitioners. The main purpose of the research being to explore political ideas in NS, empirical research concentrated on the messages being imparted by the two NS entities studied here, by perusing published material both in print and on the internet, the latter being used extensively by both, leading one analyst to use the term 'e-vangelist' to describe Ramdev, ${ }^{25}$ an epithet that can apply to Ravi Shankar and AoL as well. In addition, special attention was paid to Ramdev's television appearances, since 'televangelism' is by far the most important mode of dissemination of his message. ${ }^{26}$ Ramdev does not have a network of spiritual institutions across the country and his devotees do not usually form organised groups, being reliant on television to imbibe his message. In contrast, AoL has numerous branches throughout India, and therefore, textual research was supplemented with qualitative field-work among AoL's followers. Calcutta was chosen for field-research, in preference to other large cities such as Bangalore, Mumbai or Delhi, where AoL's following is known to be largely concentrated in the private corporate sector or the IT industry and hence concerned mainly with workplace well-being and business or corporate practice, which is not the focus of this research. In comparison, in Calcutta, IT and ITenabled industries and financial services are relatively less well developed and AoL practitioners are, therefore, drawn from a wider cross-section of the middle classes, along with some from the poorer sections of the population living in slums, where AoL members have been active in promoting spirituality, as seen above. Alongside reading printed and web-based material, I relied on around a dozen key informants who act as spiritual trainers of AoL and as coordinators of social service activities in the city, in order to gain an understanding of the main messages and ideas being disseminated in everyday practice by these key spiritual actors who are instrumental in popularising AoL in the wider community. In addition, I attended an AoL training course on spirituality, and accompanied AoL members on half-a-dozen occasions during their meetings and visits to slums and observed their work there, as described at the beginning of this essay. I also took these opportunities to engage in conversation with both middle class AoL members and the poorer beneficiaries of AoL's social work and spiritual training in slums.

\section{Art of Living and Sri Sri Ravi Shankar: Power from within}

\footnotetext{
${ }^{24}$ Nanda, God Market, pp. 92, 97.

${ }^{25}$ Santanu Chakrabarti (2012), 'The Avatars of Baba Ramdev: The Politics, Economics, and Contradictions of an Indian Televangelist' in Thomas, Pradip Ninan and Lee, Phillip (eds), Global and Local Televangelism, Palgrave MacMillan, New York, pp. 153.

${ }^{26}$ Rahul Bhatia, 'The Origins of Ramdev', Open, 2 July, 2011 http://www.openthemagazine.com/article/nation/theorigins-of-ramdev, accessed 2 March 2013; Chakrabarti, ‘Avatars of Baba Ramdev', pp. 149-170. For the importance of spiritual television channels and their growing viewership, see 'Tele-crusaders: Spirituality on the box is attracting a growing viewership', The Hindu, 23 September 2005; 'TV viewers tuned in to piety too', Business Line, 21 January 2006; 'Count Your Blessings', Outlook India, 30 January 2006; 'Spiritual Small Screen', Hindusthan Times, 2 September 2012.
} 
The Art of Living Foundation is one of India's most prominent spiritual organisations, with 350 million followers worldwide, according to the organisation's own estimates. ${ }^{27}$ It enjoys an international standing and it works with various United Nations organisations to promote peace and 'human values'. ${ }^{28}$ AoL undertakes an extensive range of educational, social service and humanitarian relief work. AoL is also well-known for the deployment of spiritual techniques in business and in the private corporate sector for human resource management, performance and productivity enhancement. ${ }^{29}$ AoL is an example of Indian spirituality influenced by its passage through the West. Ravi Shankar's early spiritual career in the 1970s was in the West, notably Switzerland, where he worked with Maharishi Mahesh Yogi, best known for his promotion of transcendental meditation and spiritual regeneration in the West. Armed with this western experience, Ravi Shankar subsequently set up his own spiritual organisation in Bangalore in the early 1980s, where AoL soon gained considerable influence and following in newly emerging IT firms and other business enterprises. AoL now has a thriving presence across India, while also claiming a global reach and a cosmopolitan outlook of international peace.

In Calcutta, AoL has a central office in a middle class area as well as a number of units in various residential localities, where training sessions and regular spiritual meetings are held in the regional vernacular Bengali or in the national language Hindi. The centres that I visited were modest places that belie a prevalent notion that AoL is an organisation of affluent, westernised IT workers who congregate in upmarket, plush venues to imbibe the teachings of a largely Anglophone guru. AoL followers in Calcutta do include young workers in the private corporate sector and the IT industry, but also middle class men and women of varying means and ages from all walks of life are involved in AoL, ranging from business and professional people with their families, to college students, school teachers, housewives and retired people. In addition to their private practice of spiritual techniques, these practitioners also meet at spiritual congregations, conduct regular workshops to recruit new followers and to spread spiritual values among school children and young people, and they participate in social service and communitybased public activities. They have, for instance, sought to take the AoL message to local slums, poor youth or street children traumatised by violence and drug abuse. As a result, AoL practitioners can now be found in slum areas and among poorer sections of the population.

The four pillars of Ravi Shankar's teachings are: sadhana or spiritual practices such as yoga and meditation; satsang or congregational prayer and spiritual discussion in the company of the holy; gaining spiritual knowledge and wisdom from the guru's teachings; and sewa or social service. ${ }^{30}$ AoL's entry level training course on spirituality and sadhana, that I attended, started by instructing novices to embrace themselves and to 'hug yourself tightly; the most loveable person on earth'. This tone had already been set by the array of posters with words of wisdom displayed on the walls of the training centre. For instance:

You are love, you are beauty

You are pure, you are surrender

You are a sandalwood tree, you have to be rubbed well

You are truth, you are fulfilment

\footnotetext{
27 The Art of Living Foundation, Maha Shivratri 2010 (Souvenir Published on the occasion of Sri Sri Ravishankar's visit to Calcutta in February 2010 ), Vyakti Vikas Kendra, Kolkata, 2010, p. 2.

${ }^{28}$ Ibid, p. 3.

${ }^{29}$ Upadhya, 'Shrink Wrapped Souls'.

30 The following account is based on AoL's publications, my attendance at a spiritual training course and discussions with AoL practitioners.
} 
You are all that you are longing for.

Life is sacred, celebrate life.

Broaden your vision, the whole world belongs to you.

From the outset, it was emphasised that the training session was focussed on one's own person'You'. We were asked why we were there and what we hoped to gain. Younger participants mentioned enhancement of concentration and performance at work and in education, or improvement in marital and other relationships, while older trainees, who were all women on this occasion, mentioned freedom from physical pain (knee, back), calmness and peace of mind, and alleviation of loneliness. We were assured that by the end of the training programme, a new perspective on life would emerge for each of us. The centrality of the individual person and his or her well-being in AoL's philosophy had been previously illustrated to me by one of the trainers as follows: 'When you meet Guruji [the term used by followers for Ravi Shankar], he looks straight at you and asks, "Are you well?" - that is his main concern, that we must all be happy.' The importance, not only of individual well-being, but also of the power of the individual self, is in tune with Ravi Shankar's emphasis, in his own words, on the divinity and infinite potential of individual selves:

The self- the atma - the energy is so powerful ... it can move mountains. Acknowledge this strength. Acknowledge this power. Acknowledge the God, the divine that you are ... and then you will be able to smile through any tough time. $^{31}$

Having been sensitised to the utmost importance of empowerment and well-being of the individual in AoL's spirituality, participants in the training session were then invited to prepare themselves for an 'amazing journey' and experience to delve into the deepest inner sanctum of their own being and glimpse a beautiful vision of themselves. It was stressed that this cannot be understood through the intellect and must be experientially embraced with sincerity and 'prayerfulness'. The trainer, being aware that I was attending the course for my research and not personal well-being, advised me to blindfold myself during meditation, in case I was tempted to take a look at my surroundings out of research curiosity, thus distracting myself from delving deeply into the inner-most recess of my own self with singular devotion. I was also specifically enjoined to 'leave your brain outside' and directed to immerse myself in spiritual experience, unencumbered by the demands of my intellect and spirit of enquiry. Intuitive and experiential knowledge, as well as self-absorption were thus highlighted as the key to spirituality.

At the heart of Ravi Shankar's teachings is Sudharshan Kriya (SK), which involves performing a set of breathing exercises to gain a vision of one's inner splendour, and which is further fortified with the practice of meditation, as well as periodically maintaining protracted intervals of silence and solitude to facilitate introspection, self-absorption and self-knowledge. SK is said to be based on ancient techniques of rhythmic breath control, but with a scientific, physiological and biological basis, relating to oxygenation of the brain as well as release of energy. ${ }^{32}$ Through SK one gains control over and regulates one's mind and emotions, thus helping to remove stress, and achieve peace, calmness, bliss and happiness, as well as the capacity for proper decision-making and assuming responsibility. Practitioners report a sense of

\footnotetext{
31 Spirituality: Talks by H. H. Sri Sri Ravishankar, p. 7.

${ }^{32}$ For the importance of science in spirituality, including AoL, see, Kathinka Frøystad (2001), 'From Analogies to narrative entanglement: Invoking scientific authority in Indian New Age Spirituality', in Lewis, James R. and Hammer, Olav (eds), Handbook of Religion and the Authority of Science, Brill, Leiden, pp. 41-66.
} 
elation and being 'high' after performing SK, so much so that it is said to wean drug and alcohol abusers away from their addictive substances. This experience of breath control and meditation is supposed to cleanse and rebalance the mind, and give a general sense of happiness and contentment with one's own lot, without dissatisfaction or complaint, transcending one's daily petty concerns. AoL members repeatedly stress that they are immensely happy and they have fun, and Ravi Shankar himself is always depicted in photographs with a smile and a happy face. 'Spirituality gives you strength, that inner strength to manage difficult situations and to keep ever smiling.' 33

At the same time as strengthening the mind, the practice of SK and meditation are supposed to enhance the level of 'prana' or life force, which energises and empowers the individual. Ravi Shankar's teachings, imparted during spiritual training sessions by the local trainers, are also published in a booklet that includes a set of 'spiritual laws', projected as universal truths, and delivered in the form of advice to conduct one's life and behaviour, and to regulate one's thoughts. ${ }^{34}$ One set of laws, concerned with 'life force', states that 'the spirit that is running your life is sacred, honour this life energy', which then releases the capacity to be generous and responsible, and in turn connects us with 'everyone and everything' and gives a sense of belonging. Life force is the only constant in one's life and it is said to be a part of 'cosmic time-space design', and it must be consolidated by nurturing and cherishing one's own self.

A motif of cleansing, purification and detoxification for self-care runs through much of AoL's training -- both physically purging toxins, pollutants and impurities from the body through meditation and vegetarianism, and psychologically exorcising negative thoughts or mental negativity and emotions, through SK. The purpose of the latter is to overcome the mental impediments imposed by one's emotions and socially conditioned ego and to delve into one's true self and achieve self-realisation, which then empowers and liberates one to act responsibly. It was explained that we are like cups and if that becomes full with emotions then it overflows with anger, so it is important to empty the vessel -- the self -- regularly through meditation and breathing, because breathing is integrally related to emotions (e.g., we hyper-ventilate when afraid; breathe slowly when we sleep calmly). Emotions are like angels (or demons) who manipulate us like puppets through negative cosmic vibrations, and it is important to propitiate and pacify them by discharging positive vibrations through bowing or genuflection towards the four cardinal points where they are notionally located: East for attachment and entanglement, South for obsession and lust, West for greed and jealousy, North for anger and arrogance.

Having been initiated into the introspective technique of SK to gain control of the mind and emotions, mobilise life force, overcome one's ego and take responsibility, some practical applications and behavioural lessons were outlined in the training course, with reference to the 'spiritual laws'. These include instructions to stop blaming others and offer only constructive criticism. ${ }^{35}$ Much emphasis was placed on mental acceptance of people and situations as they are, on saving our own mind by not being swayed by others' opinion of us, and on selfpreservation in the interest of one's own peace. The key message here was the exercise of mental detachment, and the cultivation of perseverance and patience, thus allowing life's problems to wash over one - 'letting go', in other words. However, this does not imply passivity. We were

\footnotetext{
${ }^{33}$ Spirituality: Talks by H. H. Sri Sri Ravishankar, pp. 34-6.

${ }^{34}$ Sri Sri Ravi Shankar (2005), The Seven Spiritual Laws, Vyakti Vikas Kendra, Bangalore; see also Frederique Lebelley (2010), Walking the Path, Sri Sri Publications Trust, Art of Living International Centre, Bangalore, ch. 5.

${ }^{35}$ Ravi Shankar, Seven Spiritual Laws, passim.
} 
advised that avoiding one's responsibility by blaming others would make one powerless. Instead, 'take responsibility with which comes power and belongingness'. In turn, this would enable clarity of vision, strength of conviction, and decisiveness in thought and action.

Extending the ideas of mental and emotional control, acceptance, responsibility and power, other 'rules' for self-empowerment in everyday life were outlined: 'live in the present moment, the present is inevitable', do not dwell on the past or nurture regrets, which will be debilitating. 'Give 100\%' of one's effort to a task or situation as a child does with full concentration and dedication. We were advised to appreciate that opposites - good and bad - are complimentary and that hard times and problems come to test us and help fortify our spiritual power, enabling us to become centred and balanced within ourselves: 'a problem is not a problem, how we think about it is a problem'. We were reminded that life is changeable, and were urged to accept and receive everything as part of life, and to make use of every situation in life for our growth. We were urged not to be attached to or crave joy, happiness, freedom and so on, but to 'let go' and surrender, whereupon peace and bliss would come automatically. ${ }^{36}$ Following these rules or laws, reminiscent of staple positive thinking guidance in general, but fortified and leavened with SK and meditation in this case, one is expected to achieve inner strength, determination and confidence, and with further higher levels of spiritual learning and exercise, one is 'forged into steel from inside', as an AoL practitioner stated.

\section{Baba Ramdev: Power of the healthy body and mind}

Baba or Swami Ramdev, a saffron clad sadhu (ascetic), presents himself as a Hindu, Indian ascetic, dedicated to both spirituality and patriotism. Trained at a Hindu religious seminary ('gurukul') and with various sadhus, he launched his public career as a yoga and spiritual preacher in 2002 through mass yoga camps at his ashram in north India and in various towns and cities around the country. ${ }^{37}$ Soon Ramdev became a household name as his yoga sessions at mass camps began to be televised daily on religious channels that had been launched in India from 2000 onwards. Indeed, Ramdev emerged as one of the chief drivers of the success of 'televangelism' in India, with a ubiquitous daily presence on the Aastha channel. ${ }^{38}$ Ramdev's teachings can be located within the tradition of nineteenth and twentieth century nationalist yoga, ${ }^{39}$ seeking to unite the mind, body and the soul, that are thought to have been rent apart by the deleterious influences of western modernity. In contrast to Ravi Shankar's stated commitment to international peace and harmony, Ramdev is very critical of the West. He draws upon nationalist constructions of yoga in the colonial and post-colonial periods as a spiritual tool for personal rejuvenation, as well as social and political regeneration, and moral and ethical reconstruction of the nation. He is popularly seen as India's unrivalled yoga king, and an enthusiastic preacher of health promotion and treatment through ayurveda and the classical

\footnotetext{
${ }^{36}$ Ibid.

${ }^{37}$ Ashok Raj (2010), Life and Times of Baba Ramdev, Hay House Publishers, Delhi, p. 84.

${ }^{38}$ Bhatia, 'Origins of Ramdev'; Chakrabarti, 'The Avatars of Baba Ramdev', pp. 149-170.

${ }^{39}$ Raj, Ramdev, pp. 14, 53; Alter, 'A Therapy to Live By', pp. 309-335. For the history of yoga and nationalism, see, Joseph S. Alter (2004), Yoga in Modern India: The Body between Science and Philosophy, Princeton University Press, Princeton and Oxford; Joseph S. Alter (2000), Gandhi's Body: Sex, Diet, and the Politics of Nationalism, University of Pennsylvania Press, Philadelphia, chs. 3-4; Anne-Cecile Hoyeg (2011), 'Health Yoga and the Nation: Dr Karandikar and the Yoga Therapy Centre, Pune, Maharashtra' in Berti, Daniela, Jaoul, Nicolas and Kanungo, Pralay (eds), Cultural Entrenchment of Hindutva: Local Mediations and Forms of Convergence, Routledge, London, New York, pp. 145-160.
} 
system of yoga of Patanjali (compiler of Yoga Sutra, an ancient foundational text on yoga practice), both through his mass yoga meetings around the country and his widely-watched regular television programmes. Ramdev has established a major educational and training institution for yoga and ayurveda - the Patanjali Yogpeeth Trust, located at Hardwar in north India, and he claims to have cures and preventative prescriptions for every conceivable ailment. Not only are his television programmes on religious channels extremely popular, but also CDs and DVDs of his yoga demonstrations enjoy a mass market, along with the sale of ayurvedic remedies produced at his Patanjali Trust, which is believed to have a multi-million rupee annual turnover. ${ }^{40}$

Ramdev's televised yoga demonstrations include commentaries on their efficacy for the treatment and cure of various ailments, for nurturing a healthy body and mind and for achieving spiritual elevation, interspersed with extensive discourses on ethics, politics and governance, purportedly from the perspective of the ordinary person as a citizen. In this way he directly links yoga and personal improvement with the health of the democratic polity. Unlike Ravi Shankar, he is overtly political and populist in mounting a campaign for the reform of law and governance to curb corruption and for economic development that would benefit the masses. Ramdev enjoys a mass following among the poor and rural populations, including lower castes, well beyond the urban middle classes. ${ }^{41}$ By virtue of his mass influence, Ramdev enjoys a prominent political profile, and many of his events and initiatives are attended and patronised by celebrities, politicians and social activists, even though he has been accused of tax evasion and of links with the Hindu nationalist Bharatiya Janata Party. Notwithstanding such political controversies and allegations, Ramdev remains highly influential as one of India's most widely followed spiritual teachers. While his followers attend mass yoga camps that he organises around the country, they rely primarily on the electronic media to learn about yoga and ayurveda, and practice personal health and spiritual regimes inspired by his teaching. On television, they are also exposed to Ramdev's diagnosis of India's political and social ills and their cure through yoga and spiritual rearmament.

Ramdev $^{42}$ preaches a simplified and easy to follow regime of spiritual practices, consisting of yoga (he prefers the Hindi term 'yog') and in particular, a set of breathing exercises, notably kapalbhati and pranayam, that control the mind, slow down the breath and release vital energy or prana or life force, rather like AoL. ${ }^{43}$ According to Ramdev 'while pranayams strengthen the software of the body, asanas [yoga postures] empower its hardware. ${ }^{, 4}$ It should be noted here that Ramdev's is a moral Hinduism based on physical health and yoga, rather than a primarily muscular one, usually associated with Hindu nationalist politics.

Ramdev's distinctive feature is the strong emphasis on health, which he sees as the starting point of the spiritual journey, by getting rid of lethargy and cynicism. Yoga and pranayam also launch individuals on the way to self-discovery and transformation of their thought process, marking a subjective corporeal experience of knowing oneself and embodying control and management of one's own self. The healthy body is then conceived as a suitable receptacle or repository for a

\footnotetext{
40 'Will Ramdev's success as a yoga guru stand testing-times ahead', India Today, 10 June 2011.

${ }^{41}$ Chakrabarti, 'Avatars of Baba Ramdev', p. 161.

42 The following account is based on: Ramdev's television programmes; Raj, Ramdev; and http://bharatswabhiman.com/en/archives/, accessed 8 March 2013 (this website of the Bharat Swabhiman Andolan includes a large number of speeches and lectures by Ramdev).

${ }^{43}$ Raj, Ramdev, p. 87.

${ }^{44}$ Ibid, p. 88.
} 
spiritual and moral individual, who is, in turn, the fundamental constitutive unit of a powerful nation's democratic polity.

\section{Sewa and the service ethic}

The centrality of the individual self in NS does not imply atomistic individualism nor the private practice of faith in splendid isolation. Instead, projects of self-making and self-actualisation involve acts of altruism and collaborative action, consistent with Heelas' formulation of 'relational subjectivism' or 'self-in-relation', as discussed above. A personal mission of selfimprovement leads into wider social and public engagement, notably social service, which features strongly in many versions of NS, notably that of AoL.

While Ramdev's publicly engages in a critique of the governing elite and political corruption to appeal to his mass following, Ravi Shankar advocates social compassion, humanitarian work and an ethos of service or sewa, that is eagerly embraced by the largely upper and middle-class members of AoL. Ravi Shankar propounds sewa as an essential feature of spirituality, alongside 'sadhana' or the practice of spiritual acts such as yoga and meditation. In his words,

See love inside you - that is meditation. See God in the person next to you - that is service. Service and meditation go hand in hand.... The previous century has been an era of uniforms and unions. Now let us move to an era of communion. With these few words I pray ... I take responsibility. ${ }^{45}$

Following this advice, and by abjuring any reliance on either dominant state power or collective political action ('uniforms and unions'), as well as having assumed a sense of personal or individual responsibility and self-empowerment derived from spiritual practice, the middle and upper class members of AoL usually set out to spread the benefits of their message of happiness and peace with a proselytising zeal. They target disadvantaged and marginal or deprived people, including drug and alcohol addicts, and street children, who are believed to be mentally traumatised and 'stressed' by the brutalising experience of a life of abject poverty, neglect, violence or abuse on the street. On 5 December 2012, on the occasion of the UN International Volunteer Day for Economic and Social Development, Ravi Shankar inaugurated the "Volunteer for a Better India' initiative, which invites young people to devote one hour each day on voluntary work in alliance with AoL, 'to address the critical issues affecting India like HIV and AIDS, the declining child sex ratio, sexual and reproductive health and rights, various issues affecting youth, environmental sustainability, drug and substance abuse, inequality in education and entrepreneurial opportunities, corruption and child protection issues'. ${ }^{4}$

Calcutta AoL members have set up a sheltered home for street children, animated by the same spirit as a major 'stress-free' school that has been established by AoL in Asia's largest slum of Dharavi in Mumbai, for children who are routinely exposed to violence and abuse, with the following aims:

... regular counseling sessions [are held] to help bring a child out of his/her past experiences and empower the child with tools to overcome challenges faced in the family. Regular yoga and meditation integrate these efforts and help

${ }^{45}$ Spirituality: Talks by H. H. Sri Sri Ravishankar, p. 2.

${ }^{46} \mathrm{http} / / / \mathrm{www}$.artofliving.org/sri-sri-launches-volunteer-better-india, accessed 10 March 2013. 
children to blossom, completely dropping any past insecurity and develop a shield against any negative influences present in the area. ${ }^{47}$

All the AoL members I spoke to, believed that social problems, violence and crime, that afflict such disadvantaged people, originate mainly from the stress of deprivation and insecurity, and so can be reduced by engendering mental calmness, equilibrium and contentment, of which they have a deficit. Nav Chetna Shibirs (New Awareness Camps) are organised in slums to teach breathing techniques, basic meditation, stress elimination and mental balance, as well as to promote health, hygiene, social cooperation, children's education and respect for spiritual heritage, which are thought to be lacking among slum people.

Several AoL members in Calcutta with whom I spoke on different occasions, and whom I accompanied during their work in slums, eagerly and readily explained to me why they engaged in sewa work. Everyone without exception spoke of their own self-fulfilment. Some spoke simply of the happiness and enjoyment that comes with sewa. One urban resident, in describing the experience of doing sewa work in villages in the city's outskirts, drew the analogy of going on a picnic with one's friends. One of AoL's websites displays photographs of smiling members engaged in social work, and carries the caption: 'Doing Service is Fun'. Others expanded beyond this seemingly obvious entertainment value of social work. One of the long-standing stalwarts of AoL in Calcutta, an affluent housewife, who has planned and executed various sewa initiatives in the city, stated:

I love it. It is so fulfilling. I forget all petty troubles of my own. I feel happy, all small problems, petty complaints disappear, as you see a larger vision of life - the bigger picture. ... You know, from a helicopter huge road-blocks appear to be tiny and inconsequential, just like that I don't feel hassled by every day little problems when I am doing sewa. ... You know, once Guruji [Ravi Shankar] asked a woman, who said she was unhappy in her life, 'For how many people do you live, how many do you care for?', and she said about five to eight people, then Guruji said, 'Live for all those who need you and your help, do sewa for all and you will be happy', and I know that that woman listened to Guruji's advice and she is now happy.

A young college student, a recent entrant into AoL, who teaches English to slum children, was similarly enthusiastic:

When you help others, your mind is expanded, you feel satisfaction, you feel better, you feel so good, you get energy - pranshakti. ... Sewa helps us to analyse and understand ourselves - it gives a new angle in life and helps us to strive towards perfection - until recently I was just concerned about my work and was permanently agitated, now I am more peaceful and I can take this peace to others.

Historically, social service or developmental work has not only been prominent elements of religious revivalist or reformist initiatives, but also often featured in guru-led religious groups or orders, most notably the Ram Krishna Mission, founded by Swami Vivekandanda. ${ }^{48}$ Sewa has also often been interpreted as a form of guru bhakti (devotion), whereby it is an extension of adulation for the guru, by engaging in service work at his or her behest. ${ }^{49}$ AoL members' comments suggest continuity with these earlier traditions as well as an element of guru bhakti as

\footnotetext{
${ }^{47}$ Website on Dharavi School: http://ru.artofliving.org/school-starts-asia\%E2\%80\%99s-largest-slum-dharavi; http://www.dharavischool.org/, accessed 15 October 2011.

${ }^{48}$ Beckerlegge, Swami Vivekananda's Legacy of Service.

${ }^{49}$ See discussion in Jacob Copeman and Aya Ikegame (2012), 'The Multifarious Guru: An Introduction', in Copeman, Jacob and Ikegame, Aya (eds), The Guru in South Asia: New Interdisciplinary Perspectives, Routledge, London, New York, pp. 34-35.
} 
a motivating force, but the most dominant sentiment is that of self-care and self-benefit, with some even expecting a direct return in the form of personal well-being or a fulfilment of their wishes and desires by virtue of engaging in sewa. Ravi Shankar advocates such sewa and what he calls 'random acts of kindness', without expecting any tangible returns. Yet at the same time he explains that through sewa 'good vibrations come to you' and one's karmic account receives a positive deposit. ${ }^{50}$ 'Karmic account' here invokes the law of karma that one reaps the fruits of one's actions, and refers to the 'balance sheet' of karma that has negative and positive sides. If the latter is favourable, benefits then accrue to the karmic account holder in this life. Thus, AoL followers, while speaking of 'giving something back to society', also highlight the pleasure and contentment that sewa brings to them, which enhances their own mental and spiritual well-being, transcending everyday petty cares and concerns and elevating the mind and the spirit. Doing a good deed and acts of virtue are evidently seen here through the prism of the well-being and spiritual benefit it brings to one's own self.

The ethos of social service has a long history in the Indian subcontinent. Sewa, understood as a personal duty of Hindus and as a mode of accretion of religious merit, took a more organised, public form in the colonial period, in particular. Sewa was undertaken in the service of society, community and the nation, often in an ascetic modality of self-sacrifice, selfabnegation and renunciation, and sometimes associated with Gandhi. ${ }^{51}$ In his study on social service in colonial India in the early twentieth century, Carey Watt has pointed out that service or sewa was part of India's long-standing 'living tradition' of charity and philanthropy, pre-dating the colonial period. ${ }^{52}$ Historically associated with monastic orders and ascetics, social service thrived in the colonial period among social reformers, and its remit was vastly expanded by religious revivalist and reformist organisations and the nationalist movement, thereby giving a fillip to India's associational life, and playing a critical role in configuring the nature of the public sphere and civil society. ${ }^{53}$ Social service, usually an elite and middle class activity directed at those of lower social and economic status, was primarily undertaken for community reinvigoration and for patriotic nation building. ${ }^{54}$ These activities also encapsulated characterbuilding and self-development that were geared towards forging dutiful, disciplined citizens. ${ }^{55}$ While resonating with these earlier traditions, today sewa in NS is seen primarily as a form of personal self-improvement and self-fulfilment. In this respect, the narratives of sewa among AoL members mark a striking contrast to some of these earlier traditions of the colonial period, with an inversion of the logic of service, which is now conceived to be an activity primarily for personal mental satisfaction and spiritual attainment. Nation building or community construction is a secondary concern, although inextricably linked with self-fulfilment. Altruistic actions are seen as a functional extension of the preoccupation with self-development. The motivation behind sewa is described by practitioners as individual self-purification and self-betterment, as

\footnotetext{
${ }^{50}$ Art of Living Foundation, Maha Shivratri 2010, p. 6.

${ }^{51}$ Carey Anthony Watt (2005), Serving the Nation: Cultures of Service, Association, and Citizenship in Colonial India, Oxford University Press, New Delhi, chs 1, 3-6. On Hindu nationalism and social service, see Gwilym Beckerlegge (2004), 'The Rashtriya Swayamsevak Sangh's "tradition of selfless service”, in Zavos, J., Wyatt, A. and Hewitt, V., The Politics of Cultural Mobilization in India, Oxford University Press, New Delhi, pp. 105-35.

${ }^{52}$ Ibid, p. 13.

${ }^{53}$ Ibid, pp. 1-19, passim.

${ }^{54}$ For a broader discussion of the class dimensions of Hindu revivalism and reformism in the colonial period, see Jason D. Fuller (2009), 'Modern Hinduism and the Middle Class: Beyond Revival in the Historiography of Colonial India', Journal of Hindu Studies, 2(2), pp. 160-178.

${ }^{55}$ Ibid.
} 
seen above, rather than augmenting the strength of a collective unit or community to which one belongs, be it based on religion, caste or the wider nation. The latter is an ancillary benefit, rather than being the primary driving force.

In addition to narrating the fulfilling aspect of sewa, many also explained what form of sewa was needed and why. A highly active AoL member who frequently travels to areas affected by natural calamities such as flood or cyclone, expounded the importance of spiritual intervention, as distinct from developmental aid or humanitarian disaster relief:

Relief cannot solve the problem, unless they [the victims of disaster] deal with their fear, terror, trauma - memory of the terrifying event. This has to be from within [not external aid] and sudarshan kriya and pranayam help exactly with this.

Similarly, another AoL member who coordinates AoL work with children, young people and women in a number of Calcutta slums, explained that employment generation schemes and other provision of support and services by the state were not sufficient, both because they breed dependence, and because they fail to address the root cause, which is the mind. What is needed is to "make them [inwardly, spiritually, mentally] strong and responsible to enable them to take up community issues - making them independent and committed'. She gave several examples of the efficacy of spirituality in development:

We do pro-health campaigns in slums, not about disease treatment, but about staying healthy - 90 per cent of diseases start from the mind, we can address the root cause of the problem, so we teach techniques to have a healthy mind ... And about work -- we first ask them what their problems are and when they talk about lack of ability to work, we tell them how to tackle the problem by looking after the mind. ... We give them something better than jobs - we can teach them self-confidence and personal power and inner strength and then they will be able to work; they will think their problems are less serious. ... Well look, I have changed in my own professional work - huge change - every day sadhana brings courage, centred-ness, confidence, inner strength, inside balance, not too much affected by outside conditions, I can think calmly ...

Evidently, this shift of the locus of control to the mind and inner spiritual resources discourages an engagement with socio-political complexity or with structural aspects of the economy and society. Similarly, the emphasis on individuals taking responsibility for social service goes cheek by jowl with scepticism about state action. Indeed, sewa comes to its own because the state is seen to be irrelevant and inadequate, and when 'uniforms and unions' are seen to have been detrimental to human well-being, as in Ravi Shankar's comment cited above.

In light of the above, not surprisingly, acts of giving or service are often conceived in intangible terms. Most notably love and kindness are emphasised by all, and are considered synonymous with spirituality in many cases. As Ravi Shankar says: 'To grow in unconditional love ... is spirituality'. ${ }^{56}$ For AoL, 'giving' can imply the offer of counselling, extending compassion, sharing happiness and communicating a big smile as a form of dissemination of well-being. An AoL member felt that people in slums appreciate the empathy and consideration that is extended to them and they welcomed the fact that 'we are with them'. Service and giving here are interpreted in emotional, psychological or spiritual terms, and they do not imply or are not animated by any conception of redistributive justice or social equity. One AoL practitioner who teaches meditation and spoken English to young people in slums, said, 'I cannot make them

\footnotetext{
${ }^{56}$ Spirituality: Talks by H. H. Sri Sri Ravishankar, p. 35.
} 
economically better, but I can teach them money is not all, and help them understand the value of other things'.

Carey Watt notes that in the colonial period, social work was often undertaken in cooperation with the government, but the state being colonial, the creation of an autonomous civil society and associational space by citizens was an integral dimension of social service. ${ }^{57}$ In the post-colonial period, in particular under a Nehruvian conception of a state-led developmental project, social work was brought under the purview of the state and the autonomy of NGOs was curtailed, with citizens expected to make sacrifices and fulfil their duties vis à vis the state rather than undertaking independent service work. ${ }^{58}$ In the past few decades in India, however, private involvement and voluntary engagement in the social sector has been encouraged by the state under the rubric of public-private partnership. This is one of the factors contributing to an efflorescence of social service and non-governmental developmental work, primarily in the form of activity of NGOs as privileged civil society institutions. While falling squarely within the ambit of such recent familiar NGO work, AoL's initiatives are additionally animated by the element of individual spiritual experience inspired by the guru. Such activities are conceived to supplement, even supplant, the state that is seen to have limited capacity or to have failed, requiring citizens to assume responsibility. As a veteran AoL member explained:

The government can't cope, so now Guruji and other saints are holding society together; they have stepped in, because they have the manpower - lots of dedicated followers and volunteers ready to work for society.

Here citizens of the supposedly failed state have now redirected their loyalty and allegiance to a guru, at whose behest they are willing to engage in public duty, because they have learnt the art of self-empowerment and self-realisation from the guru and have been inspired by the promise of a better life. Copeland and Ikegame, invoking Foucault, refer to 'guru governmentality', to describe the process of arrogation of developmental responsibility by spiritually animated followers of gurus and guru-led organisation, in a neoliberal policy context, in which 'the Indian state now "borrows" from or harnesses the guru-devotee relationship in order to fulfil certain governmental ends' ${ }^{59}$ Examples of this spiritually-inspired private-public synergy include AoL's 'developmental' work in slums and among disaster victims, drug addicts and street children , and further instances will be seen below in their efforts to mitigate political violence and unrest.

\section{Nationalism}

The practice of sewa, in some cases, notably AoL, extends into the promotion of the cultural, natural and spiritual heritage of the country. Sudarshan Kriya breathing technique that is at the heart of AoL's practice is itself seen as a form of resurrection of indigenous, antique knowledge. SK had supposedly been 'lost' and cast into oblivion due to western influences, but was resurrected and popularised by Ravi Shankar. In a similar vein, prominent items in the repertoire of AoL's service-oriented work with a public purpose include the preservation and celebration of national cultural and spiritual heritage and values, ranging from the nurture of indigenous

\footnotetext{
${ }^{57}$ Watt, Serving the Nation, p. 10.

${ }^{58}$ Carey A. Watt (2011), 'Philanthropy and Civilizing Missions in India c. 1820-1960: States, NGOs and Development', in Watt, C. A. (ed.), Civilizing Missions in Colonial and Post-colonial South Asia: From improvement to development, Anthem Press, London, pp. 293-303.

${ }^{59}$ Copeman and Ikegame, 'The Multifarious Guru', p. 35.
} 
treatment regimes and herbal medicine, such as ayurveda, massage and spa therapy, to the containment of environmental pollution, preservation of natural resources, including the sacred rivers of Ganga and Yamuna, the promotion and patronage of Indian classical music, revival of traditional arts, and the restoration of heritage sites, usually religious buildings and edifices. AoL also promotes value education in heritage schools called Sri Sri Academy, where 'traditional', Hindu values, etiquette and practices are inculcated, such as regular prayers, greeting with namaskar, learning to respect elders, valuing national cultural and traditional treasures.

Nationalist, patriotic and service-oriented action of this kind also includes the promotion of peace and political stability. A female AoL member recounted her own understanding of this:

... When I joined AoL I realised that spirituality is the solution to all that we are facing in life, in the system, in society - poverty, violence, terrorism, corruption, inefficiency - all arising from friction, misunderstanding, mistrust .... There is a need to spread the goodness among people ...

The bliss and contentment that is derived from meditation and Sudarshan Kriya is said to bring about peace, harmony, conflict reduction and unity among divided communities. Ravi Shankar's Geneva-based NGO that promotes peace and human values is now a consultant to UNESCO. AoL also works closely with institutions of the Indian state in prisons for the mental and moral rehabilitation of inmates through spirituality. Convicted criminals are said to be in a state of mental turmoil and negativity, and spiritual intervention is believed to be able to relieve this and help their social rehabilitation, as in the case of street children or drug users. Since stress and negativity are diagnosed as the cause, not only of crime but also of violence, AoL is active in areas of political insurgency, such as the northeast of India and areas of Maoist conflict, as well as in post-conflict and post-disaster zones for the mental relief of trauma victims and to alleviate their personal suffering. Ravi Shankar states that his vision is a violence free, stress free world, thus emphasising the direct link between the two, in his view. ${ }^{60}$ A Calcutta AoL veteran affirms this view:

There is violence and unrest and social problems wherever people are deprived and so they are stressed and angry. We go to them with love and kindness and we teach them sudarshan kriya and calm down their mind, help them to cast aside negativity, and then they can get out of violence.

A major thrust of AoL's work concerns young people as a national asset. They are believed to face the most serious social and developmental challenges, in a rapidly changing world, to cope with which their minds need to be spiritually trained. The aim of all these initiatives is to promote human values, a sense of 'belongingness' and a sense of responsibility among young people. ${ }^{61}$ AoL runs Bal Chetna Shibir (childrens' awareness camps) for children in slum areas, villages and economically backward regions, with the aim of instilling confidence, leadership qualities and a positive attitude to help lead a healthy and stress-free life. The Youth Empowerment Seminar (YES) is designed to impart life skills to cope with adolescent challenges. The Youth Leadership Training Programme (YLTP), for young people of deprived background in rural areas and in slums, is specifically geared to inspire them to undertake social service within their own communities and to help them develop a sense of civic commitment. An AoL YLTP trainer explained that the programme helps to develop confidence and mental clarity through breathing and meditation technique and also instils the right values in young people, and

${ }^{60} \mathrm{http}: / /$ www.artofliving.org/founder-vision, accessed 18 July 2012.

${ }^{61}$ Spirituality: Talks by H. H. Sri Sri Ravishankar, pp. 15-21. 
in this way equips them to take responsibility, and make the right choices and decisions. YLTP, aimed at 'building dynamic leaders for tomorrow', covers five key areas called 5H: Homes, Health, Hygiene, Harmony in Diversity and Human Values. It is described on an AoL's website as follows:

This program has a unique syllabus. Not only does the Youth Leadership Training Program focus on personal development and communication skills [sic]. Through stress-reducing breathing techniques, individuals find inner peace and communities to come together in a spirit of service. Participants are inspired to volunteer for rural projects, and the fruits of the seeds sown in the classroom can be experienced by the community as a whole. ${ }^{62}$

An AoL member who holds regular training sessions in slums and whom I accompanied to a slum, introduced me to a group of young people, mainly casual workers, who had attended YLTP. One of these men explained that through YLTP he had found the strength and initiative to work for his community: 'In the past when a drain was blocked we would wait for the municipality to do something; now I go ahead and clean it up; pull out the plastic bags that caused the blockage'. When probed further about how problems in slums might be solved with spirituality, another young man said such problems like drugs and violence could be easily solved, because spirituality was 'a new kind of intoxication -- the addiction of physical and mental improvement'. He added that peace and calmness of mind can also help with local mediation to deal with violence, and he hoped that more people would take to spirituality for this reason. On the subject of conflict, one of them, who worked as a security guard, explained that he had joined a trade union and had been aggressive at work towards his employers for treating him badly, leading to his dismissal. However, after adopting spiritual practices, he had become less confrontational in disposition, more dutiful and less adversarial, which has also meant that his new employer was now more amenable. He expanded: 'We all have internal strength, but we have to train ourselves to find that strength', which then enables one to address both personal problems and those faced by one's community. It appears from this view that young people are expected to contribute to the nation through the personal accretion of inner spiritual strength, and AoL aspires to facilitate this process.

Of all the prominent NS practitioners in India today, arguably Ramdev is by far the most explicitly nationalist with an avowedly political bent. He frequently declares rashtradharma (nationalism) to be his main ethical imperative, even more than asceticism. He sees his 'spiritual activism' as an attempt to revive a nation 'alienated from its own spiritual culture'. ${ }^{63} \mathrm{His}$ approach to nationalism has a number of different dimensions. Like AoL, he advocates the need to preserve national heritage, both natural or ecological and cultural. While both Ravi Shankar and Ramdev claim to be secular and believers in the peaceful coexistence of all communities, they also evidently seek to promote specifically Hindu culture and heritage, including the cleaning of Yamuna and Ganga as Hindu sacred rivers, as well as cow protection, in the case of Ramdev. More importantly, Ramdev's nationalist chauvinism and hostility to the West is in striking contrast to Ravi Shankar's patriotic promotion of national heritage within a broader framework of cosmopolitan internationalism, expressed in terms of world peace. Ramdev explicitly upholds Hindu health and spiritual systems as expressions of nationalist self-assertion and self-pride in a globalised, late post-colony. He proclaims the superiority of what he projects as a quintessential Indian-Hindu theory of spiritual energy as well as the tradition of ayurveda,

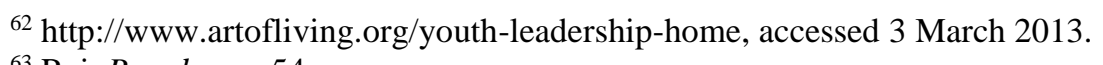

${ }^{63}$ Raj, Ramdev, p. 54. 
both having remained far beyond the comprehension of modern medical science, according to him. By advocating the widespread adoption of these and spearheading his spiritual movement with messianic zeal, he seeks to bring about spiritual self-confidence and the liberation of the post-colonial Indian mind, down to the individual level, from the enduring thraldom of colonial and western forms of knowledge. To affirm the superiority of Indian knowledge systems and to prove the efficacy of his ayurvedic remedies, he has declared his intention to initiate scientific randomised, controlled trials of his drugs.

His speeches, as well as his political commentary in the course of his yoga lessons, express a strong nationalist and anti-western sentiment, including a critique of multi-national corporations, the United States and dominant international organisations that are blamed for economically exploiting the country and relegating India to a subservient position in a neoimperial global order. A typical example of Ramdev's intermeshing of health, nutrition and yoga with a political message is, for instance, to explain the health benefits of a particular yoga posture and then to urge his followers to refrain from consuming unhealthy food, especially, 'crispy, crispy, crunchy, crunchy potato chips' of international brands that are flooding the Indian market. He explains that profit-seeking multinationals are warmly invited by greedy politicians to come to India, who then exploitatively and cheaply buy India's nutritious, natural potatoes from India's poor and toiling farmers, and mix them into pulp with artificial and unhealthy impurities to produce attractively packaged crisps, and finally sell the crisps at high prices to poor consumers in alliance with Indian corporate retailers. Thus, crisps are both detrimental to health and well-being, and instruments of neo- imperialist economic domination by multinationals, in cahoots with wealthy indigenous investors and corrupt politicians. Similarly, while emphasising the importance of hydration in a health regime, Ramdev launches into a critique about India's free-flowing, pure, natural water being collected by multinational and Indian companies, then being bottled in plastic containers that are damaging to both health and the natural environment, and sold to innocent, exploited consumers at a price. Ramdev is also concerned with village India and the regeneration of agriculture through organic farming, which would help to free poor farmers from the stranglehold of powerful multinationals that produce chemicals and artificial inputs for mechanized cultivation. He, therefore, enthusiastically advocates the boycott of foreign goods. Turning inwards to the country, he has a much vaunted political agenda of promoting corruption free governance, curbing the accumulation of large scale wealth and extending the benefits of health, education, sanitation and other necessities to the poor and the deprived. The ultimate aim here is to create a newly energised and powerful nation that will be a global power. Nature, swadeshi, indigenous heritage, anti-imperialism, nationalism and a healthy democracy all come together in Ramdev's broad-based spirituality with yoga and pranayam at its core. ${ }^{64}$

Ramdev claims that he intends to bring about national socio-political transformation and cultural regeneration through a revolution in peoples' bichar or judgement and attitudes. He has launched the Bharat Swabhiman movement or the movement for the Self Pride of India and Indians, to be rekindled through the practice of its cultural and spiritual traditions in the form of yoga and ayurveda. He has also established a political organisation composed of his disciples with the intention of nominating them to contest elections. The mission statement of Bharat Swabhiman includes the goal of $100 \%$ voting, and pledges to

\footnotetext{
${ }^{64}$ Chakrabarti, 'Avatars of Baba Ramdev', pp. 149-170; Chandrima Chakraborty (2006), 'Ramdev and Somatic Nationalism', Economic and Political Weekly, 41(5), pp. 387-390.
} 
make the entire country $100 \%$ yoga-oriented and make the citizens inward-focused by making them healthy and arouse the feeling of self-pride in each one by removing the cheating, corruption, hopelessness, disbelief and selflanguor arising because of self-confusion, and awaken India's sleeping self-respect by building national character. ${ }^{65}$

Ramdev thus argues that each individual Indian, awakened and energised through the power of yoga, imbued with ethical values and self-pride, and animated with a national purpose, will be able to contribute to the ascent of the democratic nation to international power. Ashok Raj in his book on Ramdev explains that he 'has initiated among his followers a process of self-discovery geared towards a wider cultural and spiritual self-confidence and assertion. ${ }^{66}$ Not surprisingly, Ramdev's populist and nationalist political language has earned him a substantial following. It is to be noted that while Ramdev has targeted major political and economic problems, the tool he has chosen for change is of personal health and spiritual transformation. During an interview on a national news and current affairs channel, ${ }^{67}$ Ramdev was asked to propose solutions to the problem of corrupt parliamentarians. He responded that, in the first place, they needed to be rendered mentally and physically fit. His approach appeared to be to subject politicians to spiritual purification through yoga to metamorphose them into honest and ethical servants of the people. His idea then is that of a resurgent nation, with the spiritually awakened and selfempowered individual healthy democratic citizen at its heart.

\section{Sacralisation of life}

In the West, New Age spirituality has been construed as a form of 'de-traditionalisation' and secularisation, first, because of the syncretic induction of ideas from other, non-Christian or heterodox religious systems, and second, because of the move away from organised religion and for relegating religion to the private sphere. In contrast, in India, the sacralisation of the self and everyday life marks a continuity with, rather than a break away from, established religious belief systems and practices. The significance of religious traditions is rendered more, not less, potent, precisely because of their new-found elevated personal importance and their utmost centrality in peoples' personal biographies. Moreover, there is an enhanced belief in the superiority and infallibility of religious, particularly Hindu, heritage in helping to address personal problems. In addition, the sharp distinction between organised theistic religion and a person-centric spirituality that is posited for the West, does not apply in India. As Ravi Shankar says, 'religion is the skin of the banana and spirituality is the fleshy inner fruit. ${ }^{68}$ It is hard to imagine one without the other, because they are all part of the same fruit or the same religious system. Religion, Ravi Shankar adds, has its symbols and rituals, while spirituality is the significance or essence of these rituals. ${ }^{69}$ Thus, here the rise of spirituality does not imply the erosion of religious faith, but signals deep personal rooting and internalisation of a religiously defined spiritual ethic and value system.

Moreover, existing religious beliefs are now understood in light of the central concerns of NS with an emphasis on the inner realm of the mind and soul of the individual person. Thus, for example, the festival of Navratri, which marks the slaying of the buffalo demon by the mother goddess of power -- Shakti or Devi, and symbolises the triumph of good over evil, is now

\footnotetext{
${ }^{65}$ Bharat Swabhiman website: http://bharat-swabhiman.com/en/about/, accessed 8 March 2013.

${ }^{66}$ Raj, Ramdev, p. 15.

67 'Swami Ramdev - Ek Mulakat (An interview)', DDI News Channel, 9 October 2010, 9.30 pm.

${ }^{68}$ Spirituality: Talks by H. H. Sri Sri Ravishankar, p. 35.

${ }^{69} \mathrm{Ibid}$, p. 35.
} 
reinterpreted by Ravi Shankar as a personal, inner struggle, by invoking Hindu Vedantic philosophy:

Navratri is observed to celebrate the victory of spirit over inertia, pride, shame, craving and aversion. ... we overcome our own devilish [sic] tendencies ... [we] reflect on and renew the inner depth of our lives. ... The yajnas ... [of[ Navarati ... bring rejuvenation at three levels of our existence - physical, subtle and causal. ... While fasting detoxifies the body, silence purifies speech and rests the chattering mind, and meditation takes one deep into one's own being. ... Though Navaratri is celebrated as the victory of good over evil, the actual fight is not between good and evil. From the Vedantic point of view, the victory is of absolute reality over the apparent duality. Navaratri is [the] time to drop the separatedness and recognise that life is everything. Mother Divine or pure consciousness pervades all forms... ${ }^{70}$

Similarly, the eminent management expert and author, Gurcharan Das, in his recent book, ${ }^{71}$ delineates how lessons from the epic Mahabharata can act as a guide to our personal conduct and morality, which led William Dalrymple, in a book review, to characterise this as Sanskrit selfhelp. ${ }^{72}$ 'Traditional' religion and spirituality are thus now inextricably linked, and religious deities, symbols and rituals are being reinterpreted in tune with preoccupations with the self in NS.

Nikolas Rose, in his analysis of therapeutic culture in the modern West, argues that 'the guidance of selves' does not now rest with 'religious authority or traditional morality', but with secular 'experts of subjectivity'. ${ }^{73}$ In India however, this clearly does not hold, for here religious experts and celebrity spiritual gurus, who invoke tradition and heritage, not only continue to hold sway through NS, but are also ever more dominant, arguably even more so than medical, scientific and management experts. So much so, that the latter often take recourse to NS to augment their own authority. Thus, in the realm of business and management, NS now has a central place. Similarly, spiritual healing centres are now found in major private hospitals of allopathic medicine, while India's leading cardiac surgeon recommends meditation and spirituality to prevent heart disease. ${ }^{74}$ What we witness then is the pervasive sacralisation of ever more aspects of life through the idiom of Hindu religion.

\section{Complexities of democracy, citizenship and class}

Spirituality, once the preserve of the few, is now projected as mass peoples' practice, suitable for a modern democratic nation, and geared to reshape personal destinies, through healing, health, positivity, and spiritual energisation. NS leaders and ordinary practitioners emphasise what they see as the laicisation of the esoteric, and the people-centric nature of contemporary spiritual practices. NS thus represents the democratisation and personalisation of spiritual practice, chiming with India's prevailing zeitgest of democratic participation and the normative ascendance of the idea of citizen engagement. As Warrier has argued, NS marks a 'religion of

\footnotetext{
${ }^{70}$ Sri Sri Ravishankar, 'Dip into your own nature: The Speaking Tree', Times of India, 9 October 2010.

${ }^{71}$ Gurcharan Das (2009), The Difficulty of Being Good: On the Subtle Art of Dharma, Penguin, Global.

${ }^{72}$ Review of The Difficulty of Being Good, by William Dalrymple, in The Financial Times, 24 September 2010.

${ }^{73}$ Nikolas Rose (1998: 1st paperback edn.), Inventing Our Selves: Psychology, Power and Personhood, Cambridge University Press, Cambridge, p. 151.

${ }^{74}$ From the Apollo Hospital website: http://www.apollohospitals.com/about_health.php, accessed 20 May 2012 ; 'Have a Heart', Times of India, Special Supplement: 'Celebration Times: World Heart Day', 26 September 2010.
} 
choice', personal freedom and self-authorship of religious practice. ${ }^{75}$ However, the democratic connotations and implications of NS are complex and ambiguous.

On the occasion, mentioned above, when I accompanied an AoL member to a slum where she introduced me to a group of young people who had completed YLTP, we found ourselves discussing various contemporary social and economic problems, their possible solutions and the role of political parties. One of them emphatically insisted that he had no faith in taking an active part in politics, let alone political parties, and that he thought the best way to tackle one's problems, find personal satisfaction, and indeed also to contribute to the 'country' was to improve one's own self in every way, focus on one's own work and do the best one can for one's family and oneself, rather than ruin the country through politics. In his view, to ensure the common good, it is most important to 'keep myself correct [or good]', by which he implied that one should stay focussed on one's own purpose and duty. The AoL member readily concurred, but expanded that in addition to doing one's best dutifully, one needed to 'give something back to society', such as by doing voluntary work in the slum as she was doing. All this not only gave her a sense of personal fulfilment and peace, she elaborated, but this was also much better for the country than citizens getting embroiled in opportunistic politics. Interestingly here, the notion of being a good citizen and ideas of civic virtue, virtuous politics and even nationalism or patriotism are understood not only in terms of abjuring formal 'politics', but also in terms of a particular notion of personhood involving individual transformation, self-management, selffulfilment and self-actualisation as socially desirable norms. Introspective spirituality both reflects and helps to constitute this approach to politics and citizenship.

Spirituality in this rendition is reminiscent of the notions of renunciation or detachment, not in the sense of other-worldliness, but reinterpreted as non-engagement with politics and other external aspects of reality, while concentrating instead on one's own self. This stimulates a selfabsorbed, introspective worldview and implies the irrelevance of societal structures, systems and relations in shaping lives. This is reinforced by the emphasis on affect and emotions that demands an anti-intellectual, non-analytical and uncritical approach, since the essence of spirituality, it is argued, cannot be grasped through the exercise of scientific reasoning. Recall the AoL training session I attended, where participants were urged to set aside their intellect and immerse themselves in the experience of spirituality and meditation with the innocence and trust of a child. This 'innocent', intuitive and experiential orientation not only breeds a comfortable political insouciance, but also discourages, even precludes, critical social enquiry. It buttresses a subjective, psychological approach to the social world and its problems, solutions to which are sought in personal spiritual transformation. At the same time, due to the embodiment of spirituality through yoga, problems also tend to be approached through the prism of personal health practices. In Ramdev's somaticised view of politics, for instance, political corruption is conceived as a disease of the ailing body politic that can be solved with the physical improvement and the mental and spiritual rearmament of citizens in a democracy through yoga and meditation. His emphasis is on the embodied performance of ethical politics through yoga as the locus of democratic practice of spiritually-armed individuals, as well as the site of assertion of moral citizenship.

The embodiment or somaticisation of spirituality through a focus on individual physical health, on the one hand, and the concentration on the mind as the site of spiritual action, on the other, nurture a self-absorbed and interiorised perspective. Societal problems then need not be addressed through external action, but through internal self-polishing and the cultivation of a

\footnotetext{
${ }^{75}$ Warrier, Hindu Selves, pp.14-15.
} 
healthy and balanced mind, body and spirit. While a self-reliant, self-responsible subject may be crafted in this way, the sole focus of social action and public activism then becomes the individual subject, giving rise to politics of the self. The personalisation and internalisation of politics in this way precipitates a mis-recognition of societal problems, for they come to be interpreted through the lens of personal or individual failings and deficit. For instance, left wing insurgency is understood in terms of mental aggression caused by deprivation, but the solution is to target the 'stressed' mind of the insurgent, thus homing in on the symptom rather than the cause. Similarly, if a problem proves to be insurmountable, then that has to be attributed to human failings rather than social and structural causes and constraints. Thus, such problems as poverty or violence can be seen to be overcome through human will, in turn encouraging an inclination to offer spiritual help to the deprived and the violent, or to hold them culpable for failing to surmount their own predicament and exploitation through mental effort. Furthermore, forms of contentious politics stand the risk of being denied legitimacy due to the tendency to characterise them as supposedly stress-driven and negativity-induced conflictual, confrontational or aggressive behaviour and action. Instead, much premium is placed on political consensus and accommodation, through an emphasis on acceptance, on forgiveness and on 'letting go', along with the valorisation of spiritual values and practices as the ideal mode of reform of the individual person, which is then expected to ensure societal and political stability and peace.

Various forms of spirituality, however, project different meanings and messages. Ramdev's yoga demonstrations, characterised by a strong populist rhetoric and a moral critique of government corruption, evidently seeks to appeal to the under-privileged and those who feel themselves powerless and excluded from the realm of institutional politics and being ill-served by the state. To them, the public practice of yoga in mass meetings could stand for a form of embodied democratic assertion of individual ethical citizens, similar to the act of voting during elections to register their identity as citizens. Mass yoga camps, thus, articulate the participatory ethic in politics of spiritually empowered individual citizens. The emphasis, however, remains on personal self-improvement and self-reliance, even while Ramdev's followers appear to eagerly absorb his strident critique of the government for neglecting the poor and favouring the rich.

If spirituality represents a mode of expression of democratic urges, albeit in limited ways, it also helps to articulate class and status identity. NS, as we saw in the case of AoL, stimulates a service-oriented, paternalistic, and philanthropic voluntarism, acting on the hearts and minds of those seen as the deprived. While concern with health and mental well-being is now pervasive, cutting across social and class boundaries, the penchant for sewa as a source of acquisition of spiritual merit appears to be largely confined to the upper and middle classes. As recent literature shows, from the perspective of these classes, institutional and electoral party politics is tainted by corruption, mob-mentality, lawlessness, and is seen as the preserve of self-seeking demagogues and low grade opportunistic politicians who are hungry for votes and who have undermined the moral timbre of democratic party politics and destroyed it as a noble, ethical vocation. ${ }^{76}$ In search of civic virtue and an alternative public activist role, as well as to express their own conception of ethical, responsible democratic citizenship, however, they seek a personalised idiom of voluntary action and they engage with the poor in the seemingly 'depoliticised' setting of development activity. Rather than political actors in the discredited electoral democratic political sphere, these middle class actors see themselves as responsible, active citizens engaged

\footnotetext{
76 Thomas Blom Hansen (1999), The Saffron Wave: Democracy and Hindu Nationalism in Modern India, Princeton University Press, Princeton, p. 8; SDSA Team (2008), State of Democracy in South Asia: A Report, Oxford University Press, New Delhi, p. 142.
} 
in social enterprise by devising entrepreneurial solutions to the problems of poverty and deprivation. Sewa and spiritual intervention among the poor is one such mode of engagement, as an individualised and self-actualised form of political expression through volunturism and social service, that are also redolent of the virtuous overtones of Gandhian nationalism and the ideal of self-help.

\section{Conclusion: The introspective democrat}

The two forms of NS in India, examined in this paper, seek to forge a sense of empowered individual agency and to craft modes of self-management and self-reliance. Beyond the obvious feature of self-help and self-empowerment, however, the political implications and meanings of NS are diverse and complex. While the site of spiritual transformation is the individual self, yet, as Asef Bayat has noted, such 'social nonmovements' of 'noncollective actors' can redefine political culture in profound ways. David Tacey's interpretation of NS as a democratic groundswell in the West, mentioned at the beginning of this paper, has some purchase in India, for NS is seen by practitioners as a form of democratisation of secret and sacred knowledge that had hitherto been available only to a select group of sadhus and sants (ascetics), and that has now provided an accessible language of self-help and personal empowerment for all. It has also articulated a notion of moral citizenship, with yoga, breathing exercises and related practices representing an everyday mode of embodied performance of a democratic sensibility, participatory ethic and a form of corporeal and bio-ethical assertion of the personal power of citizens. At the same time, the democratic significance or potential of NS is attenuated by being conceived in a privatised, individualised, solipsistic and somaticised or psychologised mode that limits critical engagement with structural features of hierarchy, inequality or exploitation, and deflects attention away from the intrinsically conflictual or adversarial nature of politics arising from uneven power and hegemony. The retreat into the realm of the personal and the subjective, with an introspective orientation of democratic morality and ethics, by implication constrain the inclination for engagement in contentious politics and encourage political quietism. It may even contribute to institutional disengagement from the electoral democratic political arena by putting a premium on forms of micro-politics of self-making, well-being and contentment as a personally empowering experience of citizenship.

Elements of Gordon Lynch's formulation of 'progressive spirituality' and Paul Heelas' notion of 'inner life spirituality', discussed at the beginning of this paper, can also be discerned in India, animating ethical and socially responsible practices, ranging from action for the welfare of the deprived and the benefit of the environment, to efforts at mitigating conflict and violence. Yet, the 'progressive', 'ethical' or 'liberal humanist' dimensions are compromised by the predominantly middle-class or elite character of such social action, with some peculiarly anti- or non-democratic political features in the contemporary Indian context. The concern with poverty is based on benevolent paternalism and a philanthropic orientation, as well as a psychological approach. This is in keeping with middle class and elite aversion to mass, electoral democratic party politics, on the one hand, and on the other, it reflects their unwillingness to countenance an engagement with the systemic political and social underpinnings of inequality and poverty. Moreover, the preoccupation with personal peace and social stability, and the emphasis on acceptance of reality, as well as the reliance on one's own mental resources and inner spiritual transformation, together stimulate accommodationist, or status quoist politics, rather than 
enabling transformational politics that might seek to reorder or overturn the hierarchy of status and power.

Further, NS articulates a specific form of middle class politics that posits the empowered, autonomous subject agent as the ideal citizen actor, with a ubiquitous emphasis on assuming personal responsibility. This facilitates the definition of a particular kind of social contract with the state, which is consistent with the neoliberal conception of a truncated state, especially in the social sector. The all-powerful developmental state is displaced here by the self-empowered, spiritually-armed, capable citizen protagonist, allowing the state to abdicate its developmental and welfare role. Ravi Shankar states: '... when you start demanding your rights you become weak, weak and weaker. The strong person always recognises his or her rights, duties and responsibilities. Only a weak person demands rights'. ${ }^{77}$ Rather than claiming rights from the state, citizens assume responsibility for ministering to the poor and the distressed, or for the health and well-being of the deprived through social service. This resonates with a familiar idiom of public action and social service that carries a longstanding nationalist cachet. In this way, an emerging model of welfare pluralism and privatisation in post-liberalisation India is reinforced, with the state expected to share its responsibilities extensively with the private, non-state sector, as well as with ethically and spiritually imbued individual citizens, who not only assume responsibility for themselves through forms of spiritual self-improvement and self-management, but also seek to bear a wider burden of welfare provision in a social service or sewa mode. This further feeds into a particular form of middle-class or elite self-definition and class identity that subsumes the politics of poverty alleviation in a narrative of personal self-improvement, both for themselves with sewa as the tool of self-polishing, and for the poor who are proselytised to imbibe the art of self-betterment and self-reliance through spirituality. Most importantly, spiritually-infused sewa of this kind enable the normative entrenchment and social and cultural embedding of the central precept of self-responsibility, associated with neoliberalism. ${ }^{78}$ Unlike AoL, Ramdev's spirituality, of course, appeals beyond the middle classes, but the autonomous, responsible, spiritual citizen remains at the heart of his political imagination too, in tune with his bid to cut a failed state down to size through anti-corruption legislation.

NS, as one of the most powerful social and political forces in post-liberalisation India, evidently has a significant role in redefining citizenship and political subjectivity, and also in reconfiguring the trajectory of democratic politics and the emerging corpus of political norms and ideals. While this is by far the most important dimension of NS, at the same time, it has implications for the entanglement of religion and politics. The political potency of spirituality arises from its construal as a powerful form of post-colonial nationalism that goes beyond mere political liberation from colonialism to a more comprehensive cultural, psychological and spiritual decolonisation down to the individual level, as well as an assertion of a distinct spiritual identity linked to a supposedly authentic antique religious tradition, which is also relevant for global peace. This is, to some extent, similar to the appeal of existing forms of Hindu nationalism. However, far more importantly, the fortification of personal spiritual conviction and the comprehensive and pervasive sacralisation of everyday life and personal identity through NS practices have assisted the deep personal entrenchment and reinforcement of a religious ethic. These personal forms of spiritual experience and the related practices of self-making and self-

\footnotetext{
${ }^{77}$ Spirituality: Talks by H. H. Sri Sri Ravishankar, p. 32.

${ }^{78}$ Nicholas Rose and Peter Miller (1992), 'Political power beyond the state: problematics of government', The British Journal of Sociology, 43(2), pp. 199; Thomas Lemke (2001), “"The birth of biopolitics”: Michel Foucault's lecture at the College de France on neoliberal governmentality', Economy and Society, 30(2), pp. 202.
} 
empowerment are overwhelmingly encoded in the specific idiom of Hinduism. The enhanced significance of privatised and personalised forms of Hinduism makes it ripe for appropriation for public political mobilisation, especially the variant that is yoked to the exalted ideal of asserting the power and identity of a late post-colonial mature democratic nation in the globalised world, through a process of national regeneration, spearheaded by its spiritually-armed ethical citizens, as seen in the case of Ramdev. The emphasis on individual agency and personal empowerment in NS valorises the autonomous self-governed, responsible citizen as the protagonist of a modern and modernising nation. The model here is that of a spiritually enriched or spiritually literate self-sufficient citizen, enhancing his or her own personal well-being, and in this way contributing to the highest common good - the good of the nation. Thus, a new nexus has emerged between religion and the nation, with each spiritually armed citizen seeing themselves, not as a member of an overarching religious community, but as an individual protagonist and personal agent of national transformation, seeking to establish India as a global power through self-cultivation. 